\title{
Some Methodological Concerns When Estimating the Size of Organizing Activities
}

\author{
Eric Swank, PhD \\ John D. Clapp, PhD
}

\begin{abstract}
Researchers and organizers recognize that social movements experience periods of inception, expansion, and decline. Although the movement literature is laden with numerous theoretical formulations on this topic, there are few articles that overtly address the issue of data collection. This paper addresses this methodological issue in detail. In doing so, we use previous media research and two case studies to illustrate the problems associated with the most frequently used data sources of event size. Finally, the paper suggests several research strategies that might enhance the accuracy of those studies that try to trace the protest cycles of community organizing efforts. [Article copies available for a fee from The Haworth Document Delivery Service: 1-800-342-9678. E-mailaddress: getinfo@haworthpressinc.com <Website: http:// www.haworthpressinc.com $>$ ]
\end{abstract}

KEYWORDS. Social movements, data collection, events, event size, community organizing

The size of organizing events can carry great importance to social movement participants, interested bystanders, media pundits, and pub-

Eric Swank is Assistant Professor, Department of Sociology and Social Work, Morehead State University.

John D. Clapp is Assistant Professor, School of Social Work, San Diego State University.

The authors would like to thank Karen Kovacik, Ginny Richardson, and Keith Kilty and the anonymous reviewers for their helpful comments on earlier drafts of this paper.

Journal of Community Practice, Vol. 6(3) 1999

(c) 1999 by The Haworth Press, Inc. All rights reserved. 
lic officials. Indeed, events such as the 'Promise Keepers Day' or the 'Million Man March' sparked public debates about the 'real' size of a national protest. Although public debate on the size issue is not new (Herbst, 1993), social scientists and social work researchers have written infrequently on the epistemological and methodological problems of gauging crowd size.

This paper discusses the methodological and conceptual issues related to making event size estimates. Initially, the paper delineates the commonly embraced methods of discerning event size. After a critique of common approaches, we provide two brief studies of local organizing cycles to illustrate the potential sources of bias when using different estimates of event size (antiwar and anticrime mobilizations in Southern California). Finally, we conclude with some recommendations as to how organizers and researchers might enhance the reliability and validity of the crowd counting process.

\section{THE IMPORTANCE OF SIZE}

Social movements are coalitions of loosely connected groups that attempt to change a social target (i.e., the government, a business, or the 'community'). These social movements are created when disenfranchised communities deem standard political channels as ineffective means of producing change (i.e., they have no PACs or wellplaced lobbyists to pass a bill for the group). ${ }^{1}$ Thus, they turn to the informal strategies of protest politics.

Although starting with a power disadvantage in the electoral realm, grassroots activists possess myriad potential power sources (McAdam, 1982). At the outset of a mobilization, grassroots activists may have some tangible resources such as money, xerox machines, buses, safe meeting spaces and the like. Further, movement leaders might have intangible resources like charismatic personalities, innovative thinking skills, and 'unlimited' enthusiasm and time. Thus, initially a core group of local activists might confront their opponents with indigenous resources.

However, this original round of collective activity may not achieve its goals. After an early setback a movement can either disband, maintain its small ranks, or increase the intensity of the conflict by recruiting new members or imposing new tactics (Snow \& Bedford, 1992; Tarrow, 1993; Weed, 1991). Given this, many movement organiza- 
tions try to solicit support from unattached bystanders because 'movements create bargaining resources when they activate third parties to enter the implicit or explicit bargaining arena in ways that are favorable to the protestors' (Lipsky, 1968, p. 1146).

This imperative to expand movement size (i.e., more activists) is based on the premise that an increase in movement involvement gives the movement more strength. On one level, the energy put into the recruitment process may follow some sort of a 'snowballing' effect. That is, when the movement swells, it becomes easier to persuade inactive sympathizers to join movement activities (Barkan et al., 1995; Klandermans \& Omega, 1987). Moreover, an increase in a movement's resources makes it harder for its opponents to rebuke their demands (Fisher \& Kling, 1994; Halpern, 1993; Marwell \& Oliver, 1993; Kahn, 1994; Kaminstein, 1995; McCarthy \& Zald, 1977; Mondros \& Berman, 1991). For example, university presidents are more likely to listen to student protesters when movie stars or college professors join the cause.

When organizers try to cultivate movement participation, their opponents typically try to discourage the movement's growth (Marx, 1979; Pichardo, 1995). Strong opponents can counter a movement's growth by mobilizing an uncommitted public against the activists. Further, governments and corporations can rely on brute force to smash movements (i.e., police violence toward antiwar protesters) or incite a backlash by slandering the activists' morals. Finally, a mobilization target can claim the movement is 'deviant' or insignificant by minimizing the movement's size (Everett, 1992).

\section{ESTIMATING SIZE}

When measuring a protest size, one should define the unit of analysis. Conceptually, most researchers characterize demonstrations on a behavioral level. That is, protests are usually defined as a non-institutionalized gathering of two or more people who verbally or visually present political grievances against an external target (Tilley et al., 1975).

When operationalizing a demonstration, a researcher must deal with the dimensions of space, time and size. Olzak (1989) noted that operationalizing the temporal and geographic dimensions of an event can be complex. For instance, to estimate the size of a political rally, researchers would need to determine its geographic and social bound- 
aries (i.e., those in the setting who are participants and those who are curious observers or other bystanders). In addition, researchers need to determine when an event begins and ends. Ultimately, to have reliable data, researchers must intentionally create a classification scheme that consistently categorizes this relevant information.

\section{TWO CONCERNS WHEN GATHERING DATA}

When measuring protest size, researchers and organizers must deal with some interrelated dilemmas. First, the scholar must resolve the question of how the count will be done. When adopting a counting method, the astute researcher should develop an instrument that clearly identifies its indicators. After recognizing one's indicators, the researcher must adopt a standardized procedure of counting. Second, the researcher must decide who will do the count. That is, some person must observe the phenomena to understand its dynamics. As we will see, the determination of who will be doing the data collection will have great bearing on the validity of the research.

\section{HOW TO COUNT A CROWD}

There are several ways to count a crowd. Individuals may attend a gathering and make an impressionistic 'wild guess' at the size of an event. Additionally, researchers can circulate an attendance sheet at a meeting or do a head count of people in the crowd. Finally, researchers might use the 'grid/density' approach that was originally formulated by Jacobs (1967) and later modified by Seidler, Meyer, and Gillivray (1976).

The 'grid/density' approach is a systematic method that provides an empirically based crowd count. Grid/density procedures include the following steps: (1) observe or photograph the entire crowd from an opportune vantage point; (2) apply a symmetrical grid that encompasses the established boundaries; (3) count the number of participants residing in a single grid cell; (4) determine the number of grid cells permeated by the crowd; (5) multiply the number of individuals in this single grid cell by the total number of occupied grid cells; and (6) report the product of the grid cell count by the total number of cells as the crowd count. 
For instance, researchers attempting to estimate the size of a campus protest might use the following steps. Before attending a campus demonstration they might visit the site where the event will occur. This preparation will give clues as to good vantage points and provides helpful geographical markers. While surveying the setting, they might notice that the venue contains ten square concrete slabs of uniform size. These slabs can function as grid cells in the 'grid/density' formula. Thus, when the protest reaches its peak, researchers can multiply the number of protesters in the referent slab by the number of occupied slabs. In this case, the researcher might count 56 participants in the referent slab (grid cell) and then note that all the slabs are occupied, which would result in a grid/density estimate of 560 participants.

The grid approach offers several advantages over the other ways of making estimates. First, reliability is improved because it establishes a consistent measuring approach. Second, the grid approach is less vulnerable to estimator bias than the more impressionistic methods (e.g., head counts). In effect, it easier to concentrate on a small area than it is to guess the size of a large mass of people. Third, the use of attendance sheets can become problematic in large informal settings like demonstrations (i.e., some people will not sign the sheets, the sheet can get stuck in one corner of the protest, or the sheet may even get lost). Finally, trying to do a head count is usually impossible because some people are too small to be seen (which will produce an undercount) and people move during protests (which could result in counting the same person twice or not at all).

Thus, the grid/density method is the best approach available. However, there are two shortcomings associated with this technique. Sometimes the grid approach must be discarded or modified when gatherings have a nebulous form that is not well suited to a graph approach (i.e., a circle shaped vigil or protesters seizing different sized rooms). Furthermore, given the fluid nature of demonstrations, grid cells can vary in density. This grid cell variance can skew the final count if the researcher's referent cell is an 'outlier' cell. Thus, even this reliable method of counting can only be seen as a relatively good method of producing valid estimates.

\section{WHO SHOULD DO THE COUNTING?}

Previous research has employed a wide array of data sources. Some researchers have done size estimates themselves (Edelman, 1986; Ja- 
cobs, 1967), whereas most studies have used secondary sources (those who use secondary sources can not control the method of estimation). A handful of studies relied on official archive records (i.e., Tilly et al., 1975) or activist generated histories (i.e., Hannan \& Freeman, 1987; Rupp \& Taylor, 1989), while the vast majority of studies used newspapers as their source of data (i.e., Burstein, 1985; Eisinger, 1973; Jenkins \& Eckert, 1986; Kerbo \& Shaffer, 1992; Khawaja, 1993; McAdam, 1982; Silver, 1994; Soule, 1992; Taylor \& Jodice, 1983; White, 1993). In fact, from 1980 to 1993, 28 articles in core sociological journals used newspapers as their primary source of protest information (Crist and McCarthy, 1996).

There are several reasons for the popularity of the newspaper procedure. Some authors argue that logistical issues require a dependence on newspapers. Newspapers may be the only viable data source for a grassroots mobilization of national scope (participating groups may not collect a comprehensive account of the protests, and researchers cannot attend every protest dispersed throughout the country). Similarly, if one is doing retrospective research, it is impossible to observe a bygone development. Other scholars insist that newspapers are the preferred source because they are always more accurate than the information offered by governmental officials or activists. Susan Olzak (1989) suggested that newspapers provide the most 'complete accounts of events' (p. 128) and Doug McAdam (1982) chose the New York Times as a data source because it is unlikely that the Times was guilty of failing to report a major story relevant to the [civil rights] movement' (p. 236). ${ }^{2}$

\section{THE RELIABILITY OF NEWSPAPERS}

Although some researchers have unequivocally accepted newspaper sources, others have been more skeptical. Most communication studies warn of the media distortions in protest depictions (i.e., Gitlin, 1980; Small, 1994). As a totality, these studies identify three aspects of media biases: (1) sample selection; (2) counting methods; and (3) representativeness (McCarthy et al., 1996; Mueller, 1997; Rucht \& Ohlemacher, 1992). The matter of sample selection concerns the frequency in which events are covered by the reporters in a given region. Of primary concern is whether reporters attended all of the protests that occurred in a particular region. Closely related to this concern is the 
issue of the counting procedures used to derive estimates, and the source(s) of the estimates. Researchers must consider, for instance, whether estimates came from reporters or the police and how each source determined crowd size.

Representativeness concerns the adequacy of using a single location to make inferences about an entire population. Clearly, representativeness is of greater concern for studies of national scope. For instance, research on U.S. protests would need to determine whether newspaper data from San Diego can accurately reflect similar activities in Detroit, Boise, or New Orleans.

Given these issues, Kielbowicz and Scherer (1986) noted that several 'regularities' of news production can jeopardize the reliability and validity of using newspapers to study collective action. Specifically, the authors noted the following threats to reliability and validity: (1) reporters commonly neglect the substance of political critiques, instead focusing on the dramatic and unique characteristics of the movement; (2) reporters tend to disproportionately rely on the statements of conventional authorities and officials to define the movement; (3) editors customarily send novice reporters to protests and similar events; (4) the schedules of reporter beats affect the probability of events being covered; (5) the number of media outlets within the vicinity of demonstrations affects the amount and nature of media coverage; and (6) reporters' identities, political commitments, and conceptions of professional norms influence the type of coverage that movements receive.

With these practices in place, numerous commentators have challenged the accuracy of media accounts. Many scholars insist that the media consistently miss most protests (i.e., they are weak on selection issues). For instance, the New York Times in 1968 had only 22 protest stories during one of America's most contentious years (Snyder and Kelly, 1977). More recently, a study of protests held in the District of Columbia found that only $7 \%$ of the 1,856 protests logged in police files were ever covered by the New York Times, Washington Post, ABC, NBC, and CBS (McCarthy et al., 1996). Moreover, all sources but the Washington Post covered less than $2 \%$ of the total Washington, D.C. protests (the Post covered 6\%).

Other studies suggest that this reluctance to cover protests does not apply equally to all groups (Gamson \& Wolsfeld, 1993; Gitlin, 1981). It is argued that media attention is closely related to the staff's reac- 
tions to movement goals (movements can demand incremental change or spark revolutionary ferment). They note that newspapers often fail to cover groups that challenge the elite in fundamental ways. Conversely, those mobilizations that support elite priorities are more likely to be considered 'newsworthy' by media outlets.

When 'radical' groups do receive media coverage, it is often negative. For instance, Daniel Hallin (1986) noted during the middle 1960s reporters repeatedly called antiwar protesters 'traitors,' 'hard-core deviants,' and 'young misfits who threatened law and order.' Similarly, the press has given subsequent peace mobilizations pejorative labels. Toronto newspapers accused the Canadian peace movement of being run by 'drunken youths,' 'obsessive women,' 'unrealistic students,' and 'sneaky speakers' (Stone, 1989). Along similar lines, Entman and Rojecki (1993) noted that reporters typically demonstrated a strong bias against antinuclear activists during the 1980 s by implying the movement emerged out of irrational impulses, that activists were strange, and that movement participants lacked the expertise to legitimately question policies of the U.S. government.

In contrast, media coverage of collective events that support the status quo or popular policies may receive more favorable coverage. Shoemaker (1984) found that centrist groups were commonly given the positive labels of 'hard working,' 'fair,' and 'intelligent' while oppositional groups were typically described negatively as 'traitors' or 'lunatics.' Similarly, Van Zoonen (1992) found that the liberal arm of the women's movement received better press than the movement's more radical segment.

Similarly, during the 1980 s when the federal government was touting its 'War on Drugs,' newspapers gave unprecedented coverage to the illegal drug issue. Moreover the press narrative on the drug war legitimated and beckoned citizen involvement in enforcement campaigns (Schlesinger \& Tumber, 1994; Surette, 1992). Gorelick's (1989) study of the New York Daily News found that people who participated in citizen crime prevention efforts were portrayed as 'courageous citizens' and a study of Time magazine found articles that repeatedly endorsed and glorified community programs that 'fought drug dealers' (Barlow et al., 1995). Finally, the most comprehensive study of this topic (Ericson et al., 1991) found that Canadian reporters repeatedly told their audience that 'the police are dependent on citizen involvement to detect and solve crimes' (p. 315). 
Several authors argue that these biases influence accounts of crowd size. When reporting on anticrime mobilizations Lurigio and Davis (1992) noted that 'media reports about the scope and success of antidrug activities are usually exaggerated and sensational' (p. 525). Other studies indicate that newspapers seem to undercount the size of 'liberal' or 'leftist' gatherings. Anecdotally, Todd Gitlin (1980) noticed that a New York Times reporter admittedly used police estimates that were obviously undercounts of a national protest against the Vietnam War. Similarly, Leon Mann's (1974) study of 22 U.S. newspapers found a statistical relationship between a paper's editorial position and its ability to count people at a protest (for example, the average estimates for four 'dove' papers put 33,000 participants at a 1965 antiwar demonstration, while the seven 'hawk' papers provide the average estimate of 20,600 for the same protest).

Murray Edelman's (1986) study insightfully discussed the relationship between movement goals and estimate bias. When using the 'grid/density' technique Edelman estimated the size of a Walter Mondale march around 18,000 to 20,000 participants. However, the Los Angeles Times and the Washington Post counted the crowd at over 150,000 after they listened to a police officer who based his size guesstimate on the impressionistic logic of 'when you've seen enough demonstrations, you can just tell' (Edelman, 1986, p. 3). Conversely, when Edelman turned to smaller leftist gatherings he found an inverse relationship because police sources provided lower estimates than the grid/density approach (a demonstration against the moral majority had a police estimate of 100 and grid estimate of 1,000 , an anti-KKK demonstration found a police count of 100-200 and a grid count of 350 and a Jesse Jackson speech drew 375 according to the police and 2,000 according to the grid/density method).

\section{ILLUSTRATIONS OF NEWSPAPER RELIABILITY FOR TWO LOCAL MOBILIZATIONS}

To explore this 'estimate' issue a bit further we provide a case study of an antiwar mobilization and an anticrime mobilization. These mobilizations were selected for three reasons. First, the authors gained 'first hand' estimates of the protests size by personally attending the organizing events (this allows independent measures of event size to compare with media estimates). Second, our examples are less prone 
to intervening factors because both protest cycles occurred during the same period (winter of 1990 to summer of 1992), the same geographical setting (San Diego, California), and were covered by the same newspaper (San Diego Union Tribune). Third, the mobilizations expressed divergent political agendas. The anticrime mobilizations sought to stop the actions of culturally sanctioned groups (crack users, criminals, and gang members). Further, this mobilization saw the government as an ally as it cooperated with police efforts to stop street crime. The protests against the Persian Gulf War, in contrast, challenged the foreign policy of the president of the United States. Moreover, this opposition to presidential dictates can be seen as 'radical' since it deviates from the cultural mores that links patriotism with supporting U.S. war efforts.

One author did an ethnographic study of Gulf War protesters (Swank, 1993/1994). A facet of this research involved the tracking of protest sizes in San Diego. To generate estimates of event size, the author used the grid/density approach described above. Additionally, he collected newspaper accounts of each event covered by the San Diego Union Tribune.

After doing a content analysis, Table 1 was created to juxtapose the grid and newspaper accounts. Although Table 1 indicates that both sources covered a majority of the protests, it also notes that the sources did not cover protests at the same rates. The researcher was more comprehensive by observing twenty-nine of the thirty-three protests $(88 \%)$ while the paper reported on eighteen of the thirty-three protests (55\%). Furthermore, this was not only a cosmetic difference. After running an ANOVA, the calculations indicated a statistically significant discrepancy $(\mathrm{F}$-ratio $=7.29, \mathrm{p}=.011)$.

The selection practices of both sources followed a pattern of omission. The paper routinely missed several protests during the beginning and tail ends of the protest cycle (December and February), while the researcher missed a few simultaneous protests that occurred during the surge of activism when the war started (January 17). Clearly, these temporal biases would severely undermine the paper's reliability since these omissions make the mobilization look shorter than it actually was. On the other hand, the paper was slightly better at finding protests that were occurring simultaneously around the movement's peak.

Compounding these patterns of omission are size discrepancies. When comparing the source estimates one notes both the rarity of 
TABLE 1. Size Estimates for Anti-Gulf War Activities in San Diego, CA

\begin{tabular}{|c|c|c|}
\hline Date & Researcher & San Diego Union Tribune \\
\hline $10-20-90$ & 410 & 200 \\
\hline $12-2-90$ & 150 & -- \\
\hline $12-9-90$ & 300 & -- \\
\hline $12-10-90$ & 210 & 200 \\
\hline $12-14-90$ & 30 & -- \\
\hline $12-16-90$ & 1,000 & - \\
\hline $12-23-90$ & 800 & 500 \\
\hline $12-30-90$ & 870 & -- \\
\hline $1-6-91$ & 2,020 & 500 \\
\hline $1-9-91$ & 2,000 & - \\
\hline $1-10-91$ & 200 & -- \\
\hline $1-13-91$ & 2,540 & 1,000 \\
\hline $1-14-91$ & 10,890 & 10,000 \\
\hline $1-16-91$ & 4,520 & 3,000 \\
\hline $1-17-91$ & -. & 300 \\
\hline $1-17-91$ & -- & 200 \\
\hline $1-17-91$ & -- & 300 \\
\hline $1-17-91$ & -- & 100 \\
\hline $1-17-91$ & 300 & - \\
\hline $1-20-91$ & 2,520 & 5,000 \\
\hline $1-21-91$ & 1,000 & -- \\
\hline $1-27-91$ & 1,810 & 250 \\
\hline $1-28-91$ & 80 & - \\
\hline $2-2-91$ & 100 & -- \\
\hline $2-3-91$ & 1,510 & 1,000 \\
\hline $2-3-91$ & -- & 100 \\
\hline $2-7-91$ & 400 & -- \\
\hline 2-7-91 & 500 & -- \\
\hline $2-10-91$ & 640 & 600 \\
\hline $2-17-91$ & 330 & -- \\
\hline $2-23-91$ & 1,000 & 400 \\
\hline $3-3-91$ & 300 & 300 \\
\hline
\end{tabular}

Note: Dash indicates no estimate and researcher numbers rounded down to the tenth. 
similar estimates (December 10, January 14, and February 10), and that the Tribune's crowd count exceeded the grid/density on only one date (January 10). Instead, the paper routinely provided lower estimates of the same event ( 8 out of 12 "joint estimates"). Moreover, most of the paper's counts were much smaller since six of the twelve estimates undercounted the grid approach by at least 500 people and four of the twelve undercounted a minimum of 1,500 participants (see October 20, January 6, January 27, and February 23 for cases in which the Tribune more than halved the researcher's size appraisals). Finally, the paper's selection bias undercut movement size since the paper missed some protests that had over 500 participants (December 30 and January 1).

The other author of this paper conducted research on an organizing effort to reduce alcohol and other drug (AOD) problems in a neighborhood in San Diego (Clapp, 1995). Similar to the research described above, he employed participant observation techniques to track the number and size of all events associated with the organizing effort. Clapp (1995) estimated event size by having event participants sign an attendance sheet at the beginning of each event. As each event concluded, the attendance sheet was passed around a second time to ensure everybody in attendance had signed the sheet. Although this method is less reliable than grid/density methods, it is acceptable since these events were relatively small.

Table 2 reveals some interesting findings. On the quantitative side, the paper covered four of the seven antidrug events (57\%). Also the

TABLE 2. Size Estimates for Anti-Drug Activities in San Diego, CA

\begin{tabular}{|c|c|c|}
\hline Date & Researcher & San Diego Union Tribune \\
\hline $4-10-92$ & 100 & "Over 100" \\
$4-29-92$ & 300 & 30 \\
$5-24-92$ & 110 & "Scores of People" \\
$6-10-92$ & 60 & - \\
$7-15-92$ & 60 & 75 \\
$10-7-92$ & 50 & -- \\
$10-10-92$ & 80 & -- \\
\hline
\end{tabular}

Note: A dash indicates no estimate for this event. Researcher estimates are rounded to nearest even number. 
Union Tribune showed a common progression of newsworthiness. That is, the early protest were deemed more pertinent that later protests (see Everett, 1992; Gitlin, 1980; or McCarthy et al., 1996, for discussions on how prolonged mobilizations lose their 'newsworthy' status). ${ }^{3}$ On the qualitative side, the paper used different narrative styles to describe crowd size. Instead of using exact number counts, the paper provided vague descriptive statements that seemed to imply that the crowd was larger than the researcher had estimated (April 10). Finally, the paper framed the organizing efforts in a positive light as its estimates matched or exceeded the researcher's estimate every time.

Our findings are partially consistent with previous findings. As predicted, the researchers attended more protests than the newspaper. However, the amount of newspaper negligence was less than expected. Surprisingly, our examples suggest that the San Diego Union Tribune showed a better event attendance rate than other papers. Moreover, the press showed no signs of being more reluctant to cover the 'radical' protests that challenged U.S. militarism. In fact, the Union Tribune showed an almost identical probability of covering both campaigns ( $55 \%$ to $57 \%$ ). On the other hand, these examples replicate earlier studies on the counting practices of the media. The press consistently underestimated the size at the peace vigils. Furthermore, these press counts repeatedly missed over 1,000 participants at several of these protests. In contrast, the 'anti-drug' mobilization was covered by a press that seemed to provide accurate or slightly inflated counts.

\section{IMPROVING EVENT SIZE ESTIMATES: SUGGESTIONS FOR RESEARCHERS AND ORGANIZERS}

Both the literature review and the case examples demonstrate the intrinsic weakness of relying on a single source of estimation (i.e., newspapers). To offset this shortfall, researchers and organizers can incorporate several data sources into their research design. Triangulation, or the strategic use of multiple data sources, may mitigate against the problems of error associated with using a single data source. Thus, researchers should engage in an exhaustive search for alternative data sources when they design their investigations.

This imperative to seek out numerous sources has ramifications for movement groups as well. To counter media reports, movement orga- 
nizations ought to document their own development. This means that organizations should foster and maintain their own set of competent participant researchers. Such researchers might be recruited from local universities or colleges. Moreover, the activists' use of 'scientific' crowd counting methods can potentially change the practices of the mass media. That is, reporters might be more receptive if community researchers follow positivistic protocols or activists might lobby for a new curriculum in journalism schools. ${ }^{4}$

\section{WHEN THE SAMPLE UNIT IS A LOCAL MOBILIZATION}

Our methodological suggestions have to vary with the size of the population. That is, different research options are available at the local and federal levels. When utilizing multiple data sources to investigate a regional mobilization, researchers must consider several issues. First, the best way to verify or refute media accounts is by having researchers make direct observations of the phenomena (Sarri \& Sarri, 1992). Thus, movement scholars must venture into the "sites of contention' to give their work more credence. Second, researchers should always acknowledge their source(s) of information in both their codebooks and published documents (i.e., police estimates said 'six hundred people marched on Newt Gingrich's office'). In a similar light, studies should discuss the limitations associated with their chosen sources. That is, a discerning body of knowledge arrives faster when researchers acknowledge the potential biases of their own estimates. ${ }^{5}$ Finally, scholars should try to ascertain the method in which informants came to their conclusions.

To ascertain possible biases, researchers may want to carefully interview each informant who provided an estimate. The interview schedule might contain 'open-ended' questions that ask for information on the estimation procedures. For instance, questions might focus on whether the person used a systematic approach for their estimates. Additional questions should solicit responses about the respondents' attitudes toward the mobilization (i.e., contempt or support). These questions should provide insights into the orientations and cognitive skills of informants.

After the preliminary stages of data collection, researchers may analyze their triangulated information in different ways. For those embracing a social constructionist perspective, one may visually jux- 
tapose the various source estimates in some tabular or graphic form (such as both of our tables). This comparative approach lets the reader probe the different ways in which sources construe and frame this size topic. In contrast, researchers who seek aggregate data for quantitative analysis may wish to construct a single numeric index (i.e., condense data sources into one measure). However, indices must be carefully conceived because a 'size index' requires the resolution of several pertinent dilemmas. For instance, researchers must often reconcile disparate estimates of the same event (Everett, 1992; Olzak, 1989). In some cases, the researcher may choose the estimate of one party over another. That is, one can prioritize media reports if one considers media accounts more reliable. Conversely, researchers might reconcile discrepancies by calculating the means of the multiple estimates. This averaging should be embraced if researcher consider all measures flawed. Whatever the approach taken, the researcher should have an explicit rationale for embracing their mode of aggregation.

\section{WHEN THE SAMPLE UNIT IS DISPERSED ACROSS A NATTON}

Researchers interested in national mobilizations are typically faced with the prospect of using newspaper accounts (only enormous research teams can observe the simultaneous protests that occur in all corners of the US). As noted earlier, this press dependency can be problematic since one cannot gauge media biases with comparative data. However, some other strategies may be employed to improve the quality of newspaper estimates.

The problem of 'selectiveness' can be lessened in several ways. First, the sample frame can have several newspapers (Franzosi, 1987; Meyer, 1993; Tarrow, 1993). The logic behind this suggestion is that one newspaper may cover a protest that another paper missed. In fact, Snyder and Kelly (1977) found that in the summer and autumn of 1968 the New York Times reported on 22 protests while the local papers of 43 U.S. cities covered 120 protests during the same period (this means that Times missed about $81 \%$ of the protests covered by other papers). Similarly, Swank (2000) found that the New York Times covered 54 Gulf War protests while the Washington Post, Los Angeles Times, and USA TODAY covered 448 such protests.

To optimize representativeness, the researcher should include every 
newspaper that advertises a national scope (i.e., the New York Times, Los Angeles Times, and the Washington Post). Next the researcher can scan Nexis/Lexis to read the reports of various news services (the United Press International, Gannett, or the Associated Press). After obtaining several national papers, local papers should be included in their sample. However, it is impossible to read every relevant paper in the nation. In fact, the idea to use every newspaper in the country would entail the reading of about 481,800 local newspapers that are not indexed (Olzak \& Shannahan, 1994).

There are several ways to create a more practical sample frame. Scholars may inspect every paper available at their campus or community library. Yet, this strategy will cloud the results since libraries usually subscribe to papers that fall in close proximity of that institution's community (again this means most regions of the U.S. would be ignored).

To prevent regional oversights, one can read the papers of every identified Standard Metropolitan Statistical Area (SMSA). Although the use of SMSAs would insure that all large cities get into the sample, it may also be too time consuming for researchers with limited resources. Thus, a researcher might divide the country into different sections and then access a major metropolitan paper from every region (i.e., Boston Globe for the East, Miami Herald for the South, Houston Post for the Southwest, Chicago Tribune for the Midwest, Denver Post for the Central states, and San Francisco Chronicle for the far West, the Seattle Times for the Northwest). Although this maneuver still excludes thousands of communities, this method eliminates the exclusion of entire geographical regions.

Finally, researchers can broaden their coverage by incorporating non-profit papers and periodicals into the sample. Scholars may want to look at left wing and right wing periodicals because such news sources often cover stories neglected by the mainstream media (Hallin, 1986; Small, 1994). ${ }^{6}$ Moreover, magazines which specialize in political actions may provide some relevant information (i.e., Congressional Quarterly, Washington Monthly, or Public Interest Profiles).

After designating the appropriate papers, the scholar should scan the papers' indexes for two types of articles. Then, researchers should obtain all the news stories and photographs regarding the mobilization. These 'objective' stories and photo captions will furnish most of 
the paper's size estimates. The language and narrative structure of these stories can also denote the political position of the reporter (i.e., the adjectives attached to participants and the labels affixed to movement tactics). Also, researchers may want to scan the editorial pages for essays and cartoons that blatantly express the management's position on the goals and actions of the mobilization (Mann, 1974). Obviously, the qualitative reading of paper portrayals can be incorporated into a paper's methods section because these portrayals can serve as indirect indicator of newspaper bias.

\section{CONCLUSION FOR RESEARCHERS AND ORGANIZERS}

This paper highlights the problems of gauging movement size. Researchers and organizers must describe events and devise a coherent plan to count event participants. They must also choose between the use of primary or secondary sources. Obviously the decision to utilize secondary sources may be fraught with problems because the accounts of activists, law enforcement personnel, and reporters alike seem to have a partisan edge. To partially counteract these ostensible sources of cstimate bias, the rescarcher may cmbrace the 'triangulation' approach. Even so, individuals should remember that innovations of research methods can only improve the quality of estimates and that no technique can yield the 'perfect' estimation of crowd size.

Finally, the enhancement of methodological accuracy is not an end in itself. To actually alter public perceptions, researchers must find ways to distribute these findings to the general populace. Otherwise, finding better measurements might be an intellectual game that never challenges cultural misconceptions. That is, without the reading of sound research, large contingencies of Americans will believe that most feminists burn their bras, Vietnam veterans were continually spat on, nobody protested Reagan's Central American interventions, and recent welfare reforms met no public opposition.

\section{NOTES}

1. Social movement activities can take many forms (i.e., recruitment drives, organizational meetings, letter writing campaigns, lobbying efforts). The act of protesting is but one option of the continuum of movement tactics, but this act of "demonstrating" is the distinct quality that separates a social movement from an interest group. 
2. McAdam writes that the New York Times is a more robust source since nine early descriptions of movement activities found 536 protests while the Times reported on 4,817 protests (1982, p. 237).

3. In an interesting aside, the newscasts of the three local television stations covered every protest. However, the televised stories focused on visual images and never gave crowd estimates in their narratives.

4. The works of D'Agostino and Tafler (1995) and Wallack, Dorfman, Jernigan, and Themba (1993) describe the innovations used by activists to get media attention.

5. However, with the current practices of publishing, many authors are reluctant to admit major measurement flaws (i.e., most studies never reveal their survey measures). This reticence seems based on the fear that it is easier to publish works which pretend to have few shortcomings. Thus, researchers intentionally gloss over problems since they want to leave the impression of an impeccable research design.

6. Some left leaning magazines are In These Times, National Guardian, the $\mathrm{Na}$ tion, and the Progressive, while the magazines National Review, Conservative Chronicle, and the American Spectator can provide the conservative spin. However, one should remember that these activist-oriented magazines also can be infected by a severe case of bias.

\section{REFERENCES}

Barkan, S., Cohen, S., \& Whitaker, W. (1995). Beyond recruitment: Predictors of differential participation in nation antihunger organization. Sociological Forum, I0, 113-134.

Barlow, M., Barlow, D., \& Chiricos, T. (1995). Mobilization support for social control in a declining economy: Exploring ideologies of crime news. Crime and Delinquency, 41, 191-204.

Burstein, M. (1985). Discrimination, jobs, and politics. Chicago: University of Chicago Press.

Clapp, J. D. (1995). Organizing inner city neighborhoods to reduce alcohol and drug problems. Journal of Community Practice, 2(1), 43-60.

Crist, J. and J. McCarthy. (1996). "If I had a hammer" the changing methodological repertoire of social movement research. Mobilization, 1 (2), 87-102.

Edelman, M. (1986). Crowd estimation. Paper presented at the Association for Public Opinion Research, May 6, St. Petersburg, FL.

Eisinger, D. (1973). The condition of protest in American cities. American Political Science Review, 67, 11-28.

Entman, R., \& Rojecki, A. (1993). Freezing out the public: Elite and media framing of the anti-nuclear movement. Political Communication, 10, 155-173.

Ericson, R., Baranek, P., \& Chan, J. (1991). Representing order: Crime, law and justice. Toronto: University of Toronto.

Everett, K. (1992). Professionalization and protest. Social Forces, 70, 957-975.

Fisher, R., \& Kling, J. (1994). Community organization and new social movement theory. Journal of Progressive Human Services, 5(2), 5-25.

Francosi, R. (1987). The press as a source of socio-historical data. Historical Methods, 20, 5-15. 
Gamson, W., \& Wolsfeld, G. (1993). Movements and media as interacting systems. Annals of the American Academy of Political and Social Sciences, 63, 114-125.

Gitlin, T. (1980). The whole world is watching. Berkeley: University of California.

Gorelick, S. (1989). 'Joining our war': The construction of ideology in a newspaper crime fighting campaign. Crime and Delinquency, 35, 421-436.

Hallin, D. (1986). The uncensored war. Berkeley: University of California.

Halpren, R. (1993). Neighborhood-based initiatives to address poverty. Journal of Sociology and Social Welfare, 20(4), 111-135.

Haney, R. (1993). Agenda setting during the Persian Gulf crisis. In B. Greenberg \& W. Gantz (Eds.), Desert Storm and the mass media (pp. 113-124). Creskill: Hampton Press.

Hannan, M., \& Freeman, J. (1987). The ecology of organizational funding. American Journal of Sociology, 92, 910-934.

Herbst, S. (1993). Numbered voices. Chicago: University of Chicago Press.

Jacobs, H. (1967). To count a crowd. Columbia Journalism Review, 6, 36-40.

Jenkins, J., \& Eckert, C. (1986). Channeling black insurgency. American Sociological Review, 51, 812-829.

Kahn, M. (1994). Organizing for structural change. Journal of Community Practice, 1(1), 87-111.

Kaminstein, D. (1995). A resource mobilization analysis of a failed environmental protest. Journal of Community Practice, 2(2), 5-33.

Kerbo, H., \& Shaffer, R. (1992). Lower class insurgency and the political process. Social Problems, 39, 139-153.

Khawaja, M. (1993). Repression and popular collective action. Sociological Forum, $8,47-71$.

Kielbowicz, R., \& Scherrer, C. (1986). The role of the press in the dynamics of social movements. Research in Social Movements, Conflict, and Change, 9, 71-96.

Klandermans, B., \& Omega, D. (1987). Potentials, networks, motivations, and barriers: Steps toward participation in social movements. American Sociological Review, 52, 519-531.

Lipsky, M. (1968). Protest as a political resource. American Political Science Review, $62,1144-1158$.

Lurigio, A., \& Davis, R. (1992). Taking the war on drugs to the streets. Crime and Delinquency, $38,522-538$.

Mann, L. (1974). Counting the crowd: Effects of editorial policy on estimates. Journalism Quarterly, 51, 278-285.

Marwell, G., \& Oliver, P. (1993). The critical mass in collective action. New York: Cambridge University Press.

Marx, G. (1979). External efforts to damage or facilitate movements. In M. Zald \& J. McCarthy (Eds.), Dynamics of social movements. Cambridge: Winthorpe Press.

McAdam, D. (1982). Political process and the development of black insurgency. Chicago: University of Chicago Press.

McCarthy, J., McPhail, C., \& Smith, J. (1996). Images of protest: Dimension of selection bias in media coverage of Washington demonstrations. American Sociological Review, 61, 471-99. 
McCarthy, J., \& Zald, M. (1977). Resource mobilization and social movements. American Journal of Sociology, 82, 1212-1241.

Meyer, D. (1993). Institutionalizing dissent. Sociological Forum, 8, 157-179.

Mondros, J., \& Berman, R. (1991). The relevance of stages of group development theory to community organization practice. Social Work With Groups, 14, 203-221.

Mueller, C. (1997). International press coverage of East German protest events. American Sociological Review, 62, 820-32.

Olzak, S. (1989). Analysis of events in the study of collective action. Annual Review of Sociology, 15, 119-141.

Olzak, S., \& Shanahan, S. (1994). School desegregation, interracial exposure, and antibusing activity. American Journal of Sociology, 100, 196-241.

Pichardo, N. (1995). The power elite and elite driven countermovements. Sociological Forum, 10, 21-49.

Rucht, D., \& Ohlemacher, T. (1992). Protest event data: Uses and perspectives. In M. Dianai \& R. Eyerman (Eds.), Studying collective action. London: Sage.

Rupp, L., \& Taylor, V. (1987). Survival in the doldrums. New York: Oxford University Press.

Sarri, R., \& Sarri, C. (1992). Organizational and community change through participatory action research. Administration in Social Work, 16, 99-122.

Schlesinger, P., \& Tumber, H. (1994). Reporting crime. Oxford: Clarendon Press.

Seidler, J., Meyer, K., \& Gillivray, L. (1976). Collecting data on crowds and rallies. Social Forces, 55, 507-519.

Shoemaker, P. (1984). Media treatment of deviant political groups. Journalism Quarterly, 61, 66-75.

Silver, B. (1994). Cycles of hegemony and labor unrest. In V. Bornschier (Ed.), Conflicts and departures in the world society. London: Transaction Books.

Small, M. (1994). Covering dissent: The media and the anti-Vietnamese War movement. New Brunswick: Rutgers.

Snow, D., \& Bedford, R. (1992). Master frames and protest cycles. In A. Morris \& C. Mueller (Eds.), Frontiers of social movement theory. New Haven: Yale Press.

Snyder, D., \& Kelley, W. (1977). Conflict intensity, media sensitivity, and the validity of newspaper data. American Sociological Review, 42, 105-123.

Soule, S. (1992). Populism and black lynching in the south. Social Forces, 71, 431-449.

Stone, S. (1989). The peace movement in Toronto newspapers. Canadian Journal of Communication, 14, 57-69.

Surette, R. (1992). Media crime and criminal justice. Pacific Grove, CA: Brooks/ Cole Publishing.

Swank, E. (1993-94). Shall we overcome? The sense of power among Gulf War protestors. Critical Sociology, 20, 31-51.

Swank, E. (2000). Who can you trust? Determining the credibilities of newspapers that cover protest mobilizations. Research in Social Movements, Conflict, and Change.

Tarrow, S. (1993). Cycles of collective action. Social Science History, 17, 281-299. 
Taylor, C., \& Jodice, D. (1983). World handbook of political and social indicators. New York: Yale Press.

Tilly, C., Tilly, L., \& Tilly, R. (1975). The rebellious century. Cambridge: Harvard Press.

Van Zoonen, E. A. (1992). The women's movement and the media: Constructing a public identity. European Journal of Communication, 7(4), 453-476.

Wallack, L., Dorfman, D., Jernigan, D., \& Themba, M. (1993). Media advocacy and public health. Newbury Park, NJ: sage.

Weed, F. (1991). Organizational mortality in the anti-drunk driving movement. Social Forces, 69, 851-868.

White, R. (1993). On measuring political violence in Northern Ireland. American Sociological Review, 58, 75-85.

for faculty/professionals with journal subscripton recommendation authority for their institutional library. .

If you have read a reprint or photocopy of this article, would you like to make sure that your library also subscribes to this journal? If you have the authority to recommend subscriptions to your library, we will send you a free sample copy for review with your librarian. Just fill out the form below-and make sure that you type or write out clearly both the name of the journal and your own name and address.

( ) Yes, please send me a complimentary sample copy of this journal:

(please write in complete journal title here-do not leave blank)

I will show this journal to our institutional or agency library for a possible subscription.

The name of my institutional/agency library is:

NAME:

INSTITUTION:

ADDRESS:

CITY: STATE: ZIP:

Return to: Sample Copy Department The Haworth Press, inc. 10 Alice Street, Binghamton, NY 13904-1580 
